\title{
COMPARATIVE GENETICS OF YELLOWSTONE NATIONAL PARK, MONTANA AND ARCTIC GRAYLING POPULATIONS
}

\author{
Ernest R. Vyse \\ Department of Biology \\ Montana State University \\ Bozeman, Montana 59717
}

\begin{abstract}
This is a report of investigations of the genetic structure of grayling populations in Yellowstone National Park and the Bighole River, Montana. This research is an extension of a comparative genetic study of Yellowstone National Park and Arctic grayling. This research was supported by the Rocky Mountain Parks Study Program. I appreciate the assistance of the personnel of Yellowstone National Park and Montana Fish and Game in obtaining the necessary samples. In particular J. Varley and R. Jones YNP are to be thanked for their assistance.
\end{abstract}

\section{Study Objectives}

A. Compare the genetics of the Bighole River adfluvial form of Montana grayling populations, to lacustrine forms in Yellowstone National Park and to Arctic grayling.

B. Determine if there are unique strains of lacustrine and adfluvial grayling to aid in restoration programs in Yellowstone National Park.

\section{Methods}

Populations of grayling sampled included Grebe and Wolf Lakes in Yellowstone National Park and Mussigbrod reservoir and the braided section of the Bighole River near Wisdom, Montana. Populations were sampled both by electrofishing and angling. Tissue samples were taken immediately and frozen on dry ice. Blood samples were kept on ice until cells and serum could be separated by centrifugation and then stored at $-50^{\circ} \mathrm{C}$. Tissue samples were prepared by grinding in an equivalent volume of $0.01 \mathrm{M}$ tris-HCl buffer $\mathrm{pH} 6.8$ containing $0.001 \mathrm{M}$ EDTA and $5 \times 10^{-5} \mathrm{M}$ NADP. The homogenate was centrifuged at $15,000 \mathrm{~g}$ for 20 minutes in a refrigerated centrifuge.

Horizontal starch gei electrophoresis was performed according to the methods described by Selander et al. 1971; Allendorf et al. 1974, and Harris and Hopkinson, 1976. Staining procedures are also described by these authors. 
Loci were designated $1,2,3 \ldots$, in order of increasing anodal migration of the coded proteins. The alleles at a locus were numbered according to the relative mobility of their isozymes under the electrophoretic conditions used. The allele with the most common frequency was designated 1.00 and alleles corresponding to faster or slower migrating bands were arbitrarily assigned values relative to the most common allele.

The buffer combinations used in the study are as follows: Buffer System $A=$ Gel Buffer: $\mathrm{pH} 8.7,0.076 \mathrm{M}$ tris, $0.005 \mathrm{M}$ citrate; Electrode buffer; $\mathrm{pH} 8.2,0.30 \mathrm{M}$ borate, sodium hydroxide. Buffer System $B=$ Gel buffer $\mathrm{pH} 6.7,0.008 \mathrm{M}$ tris, $0.003 \mathrm{M}$ citrate; Electrode buffer $\mathrm{pH} 6.3,0.223 \mathrm{M}$ tris, $0.086 \mathrm{M}$ citrate. Buffer System $C=$ Gel buffer $\mathrm{pH} 8.0,0.228 \mathrm{M}$ tris, $0.0052 \mathrm{M}$ citrate; Electrode buffer $\mathrm{pH} 8.0$, 0.687 M tris, 0.157 M citrate. Buffer System $D=$ Gel buffer pH 8.0, $0.03 \mathrm{M}$ tris, $0.005 \mathrm{M}$ citrate, Electrode buffer $\mathrm{pH} 8.3,0.06 \mathrm{M}$ lithium hydroxide, $0.3 \mathrm{M}$ borate. Buffer System $E=$ Stock solution A pH 8.1,

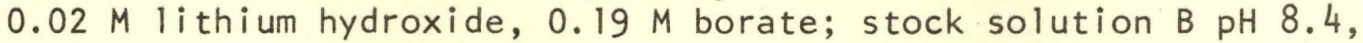
$0.05 \mathrm{M}$ tris, $0.008 \mathrm{M}$ citrate, Gel buffer 1:0 mixture stock solution $A$ and $B ;$ Electrode buffer stock solution $A$.

The buffer system used and the proteins surveyed electrophoretically are as follows: Buffer System A - Glucose -6- phosphate dehydrogenase G6PD (1.1.1.49); Hexose-6-phosphate dehydrogenase - H6PD (1.1.1.47); Phosphoglucomutase - PGM (2.7.5.1); Xanthine dehydrogenase - XDH (1.1.1.25). Buffer System B - Isocitrate dehydrogenase - IDH (1.1.1.42); Malate dehydrogenase - MDH (1.1.1.37); Malic enzyme - ME (1.1.1.40). Buffer System C - Alpha - glycerophosphate dehydrogenase - AGPD $(1.2 .1 .12)$; Glutamate oxaloacetate transaminase - GOT (2.6.1.1). Buffer System D - Alcohol dehydrogenase - ADH (1.1.1.1); Lactate dehydrogenase - LDH (1.1.1.27); Superoxide dismutase - SOD (1.15.1.1); Sorbital dehydrogenase - SDH (1.1.1.14). Buffer System E - Esterase Est (3.1.1.1), Transferrin - Tfn, Serum proteins - SP.

\section{Results and Discussion}

We have examined electrophoretically the proteins produced by 30 presumptive loci in Thymallas arcticus from Yellowstone National Park and Bighole River populations. No significant differences have been found between the Bighole River population and the Yellowstone Park population (Tables $1 \varepsilon 2$ ).

The Bighole River populations appear not to have suffered from interbreeding with arctic grayling transplants because the H6PD and SP-2 proteins found are identical to those in the Yellowstone Park populations and not in the Arctic grayling populations analyzed previously. The Bighole River populations studied appear to be pure populations of Montana grayling. We have been unable to identify any proteins variants which are unique to Bighole River grayling. 
Although no genetic markers have been found to distinguish between the lacustrine (YNP) and adfluvial (Bighole River) grayling there is a behavioral difference between these populations. Initial attempts to establish grayling in a stream in Yellowstone National Park were unsuccessful because the fish derived from Grebe Lake failed to hold stream position while fish from the Bighole River in a latter transplant have apparently maintained stream position. We are extending this analysis to include additional loci to find, if possible, genetic markers which will clearly separate lacustrine and adfluvial grayling.

\section{Literature Cited}

Allendorf, F. W., F. M. Utter, and B. P. May, (1975) Gene duplication within the family Salmonidae: 11 . Detection and determination of the genetic control of duplicate loci through inheritance studies and the examination of populations. pp. 415-432. In: Isozymes IV: Genetics and Evolution. Edited by C. L. Markert. Academic Press, New York.

Harris, H. and D. A. Hopkinson. (1972) Average heterozygosity per locus in man: an estimate based on incidence of enzyme polymorphism. Ann. Hum. Genet. 36: 9-20.

Selander, R. K., M. H. Smith, S. Y. Yang, W. E. Johnson and J. B. Gentry. (1971) Biochemical polymorphism and systematics in the genus Peromyscus. 1. Variation in the old field mouse (Peromyscus polionotus). Studies of Genetics VI. (Univ. of Texas Publ. No. 7103) pp. 49-90. 
Table 1. Monomorphic Loci.

Number of Individuals Sampled

Yellowstone National Park

$\underline{\text { Loci }}$

LDH $1-5$

$\mathrm{MDH}_{\mathrm{S}} \quad 1 \& 2$

$\mathrm{MDH}_{\mathrm{m}}$

G6PD 1E2

$\mathrm{ADH}$

PGM $1-3$

Est.

SOD

$M E_{m}$

$M E_{S} \quad 1 \& 2$

AGPD $1 \& 2$

H6PD*

SDH

$\mathrm{XDH}$

SP $2 \varepsilon 3 \% *$
Grebe Lake Wolf Lake

30

30

30

30

30

30

30

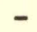

30

30

30

30

30

30
22

22

22

22

22

22

22

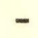

22

22

22

22

22

22

-
Bighole River

Mussigbrod Res. River

32

18

32

18

32

18

32

18

32

18

32

18

32

18

5

32

18

32

18

32

18

32

18

32

18

32

18

27

10

*H6PD - isozyme in the Bighole River populations was identical to the Yellowstone Park populations and different from the Arctic grayling populations.

$* * S P-2$ - protein in the Bighole River samples was identical to the Yellowstone Park populations samples and different from the Arctic grayling populations. 
Table 2. Allelic frequencies of polymorphic loci in the populations studied.

\begin{tabular}{|c|c|c|c|c|c|}
\hline \multirow[b]{2}{*}{ Loci } & \multirow[b]{2}{*}{ Alleles } & \multicolumn{2}{|c|}{ Yellowstone National Park } & \multicolumn{2}{|c|}{ Bighole River } \\
\hline & & Grebe Lake & Wolf Lake & Mussigbrod Res. & River \\
\hline $\mathrm{IDH}_{\mathrm{S}}$ & $\begin{array}{l}1.00 \\
1.20\end{array}$ & $\begin{array}{l}0.98 \\
0.02\end{array}$ & $\begin{array}{l}0.98 \\
0.02\end{array}$ & $\begin{array}{l}1.00 \\
0.00\end{array}$ & $\begin{array}{l}0.97 \\
0.03\end{array}$ \\
\hline G6PD-3 & $\begin{array}{l}1.00 \\
1.10\end{array}$ & $\begin{array}{l}0.92 \\
0.08\end{array}$ & $\begin{array}{l}0.98 \\
0.02\end{array}$ & $\begin{array}{l}0.95 \\
0.05\end{array}$ & $\begin{array}{l}0.94 \\
0.06\end{array}$ \\
\hline$S P-1$ & $\begin{array}{l}1.00 \\
1.10\end{array}$ & $\begin{array}{l}0.60 \\
0.40\end{array}$ & $\begin{array}{l}0.51 \\
0.49\end{array}$ & $\begin{array}{l}0.83 \\
0.17\end{array}$ & $\begin{array}{l}0.70 \\
0.30\end{array}$ \\
\hline
\end{tabular}

